\title{
ANALISIS PERKERASAN JALAN PRAMUKA KECAMATAN GANDUS KOTA PALEMBANG DITINJAU DARI SEGI BIAYA
}

\author{
SS Purwanto ${ }^{1)}$, Tommi Putra ${ }^{2)}$ \\ Dosen Fakultas Teknik Universitas Palembang ${ }^{1)}$ e-mail : ssp_3981@yahoo.co.id \\ Mahasiswa Fakultas Teknik Universitas Palembang ${ }^{2)}$ e-mail : tommiputr4@gmail.com
}

\begin{abstract}
Abstrak
Pembangunan infrastruktur jalan dimaksudkan untuk memenuhi kebutuhan sarana dan prasarana penunjang trasportasi sehingga memberikan manfaat bagi warga pemukiman dalam menghubungkan satu pemukiman ke pemukiman lainnya yang pada akhirnya diharapkan meningkatkan perekonomian kawasan tersebut. Tujuan dari desain teknis perkerasan ini pada analisis ini adalah untuk mengetahu tebal perkerasan lentur dan perkerasan kaku serta menentukan jenis perkerasan yang cocok ditinjau dari segi biaya Dalam menentukan tebal perkerasan jalan menggunakan metode "Manual Perkerasan Jalan 04/SE/Db/2017", Pedoman Perencanaan Tebal Perkerasan Lentur Pt T-01-2002", "Perencanaan Perkerasan Jalan Beton Semen, Pd T-14-2003". Data yang diperlukan adalah data CBR tanah dan data LHR. Dari analisis yang telah dilakukan, dapat diketahui tebal perkerasan lentur $\mathrm{AC}-\mathrm{WC}=40 \mathrm{~mm}, \mathrm{AC}-\mathrm{BC}=60 \mathrm{~mm}$, LPA Kelas A $=400 \mathrm{~mm}$, tebal perkerasan kaku AC-WC $=25 \mathrm{~mm}$, Tebal pelat $=180 \mathrm{~mm}$ dan LPA Kelas A $=125 \mathrm{~mm}$. Dari perhitungan biaya dapat disimpulkan bahwa pekerasan kaku dapat menghemat biaya sebesar $25,36 \%$, untuk daerah dengan lalu lintas rendah.
\end{abstract}

\section{Kata Kunci : Perkerasan Lentur, Perkerasan Kaku, Biaya Kontruksi}

\section{PENDAHULUAN}

Pembangunan infrastruktur jalan dimaksudkan untuk memenuhi kebutuhan sarana dan prasarana penunjang trasportasi sehingga memberikan manfaat bagi warga pemukiman dalam menghubungkan satu pemukiman ke pemukiman lainnya yang pada akhirnya diharapkan meningkatkan perekonomian kawasan tersebut.

Salah satu faktor yang berpengaruh pada pemilihan solusi desain tebal perkerasan jalan adalah anggaran biaya kontruksi dan periode oanggaran pembangunan kontruksi. Dengan demikian pemilihan solusi desain tebal perkerasan didasarkan pada analisi biaya umur layanan termurah dan pertimbangan sumber daya kontruksi dengan desain minimum. Karena dalam pembangunan perkerasan jalan membutuhkan anggaran biaya kontruksi yang cukup besaar, maka dengan membandingan tebal perkerasan lentur dan tebal perkerasan kaku diharapkan didapatkan tebal perkerasan yang tepat sehingga didapatkan alternatif solusi dari permasalahan tersebut.

Sejalan dengan meningkatnya kegiatan dan layanan yang harus diberikan kepada masyarakat di Kota Palembang, maka dibutuhkan sarana dan prasarana Jalan yang lebih memadai. Setiap bangunan jalan harus diwujudkan dan dilengkapi dengan peningkatan upaya mutu dan kualitas jalan, sehingga mampu memenuhi sacara optimal sesuai dengan fungsinya, dan dapat menjadi teladan bagi lingkungannya, serta memberi kontribusi positif bagi perkembangan suatu kawasan.

Dalam penulisan tugas akhir ini lokasi yang dipakai adalah Jalan Pramuka Kecamatan Gandus. Jalan Pramuka ini merupakan jalan akses menuju Taman Bumi Perkemahan Pramuka Gandus. Jalan 
pramuka ini merupakan jalan poros baru menuju ruas Jl. Tanjung Barangan - Jl. lebung Permai - Jl. Mayor H. Husni R. Tatanggano - Jl. R. Dentejik Asaari. Ruas jalan itu merupakan ruas jalan yang menuju jalan Nasional yaitu Jl. Soekarno Hatta sehingga keberadaan jalan Pramuka dapat membuka ruas baru sehingga bisa mempersingkat jarak tempuh.

\section{TINJAUAN PUSTAKA}

\subsection{Definisi Jalan}

Menurut undang - Undang Republik Indonesia nomor 38 Tahun 2004, Jalan adalah prasarana transportasi darat yang meliputi segala bagian jalan, termasuk bangunan pelengkap dan perlengkapannya yang diperuntukan bagi lalu lintas, diatas permukaan tanah, dibawah permukan tanan dan/atau air, serta di atas permukaan air, kecuali jalan kereta api, jalan lori, dan jalan kabel.

\subsection{Klasifikasi Jalan}

\subsubsection{Klasifikasi Jalan Berdasarkan Peruntukannya :}

1. Jalan Umum yaitu jalan yang diperuntukan bagi lalu lintas umum (selanjutanya disebut sebagai Jalan);

2. Jalan Khusus yaitu jalan yang dibangun oleh instansi, badan usaha, perseorangan, atau kelompok masyarakat untuk kepentingan sendiri.

\subsubsection{Klasifikasi Jalan Menurut Sistem Jaringan :}

1. Sistem jaringan primer : merupakan sistem jaringan jalan dengan peranan pelayanan distribusi barang dan jasa untuk pengembangan semua wilayah di tingkat nasional, dengan menghubungkan semua simpul jasa distribusi yang berwujud pusat-pusat kegiatan;

2. Sistem jaringan sekunder : merupakan sistem jaringan jalan dengan peranan pelayanan distribusi barang dan jasa untuk masyarakat di dalam kawasan perkotaan.

\subsubsection{Klasifikasi Jalan Berdasarkan Fungsi :}

1. Jalan Arteri : merupakan jalan yang berfungsi melayani angkutan utama dengan ciri perjalan jauh, kecepatan ratarata tinggi, dan jumlah jalan masuk dibatasi secara berdaya guna;

2. Jalan Kolektor : merupakan jalan yang berfungsi melayani angkutan pengumpul atau pembagi dengan ciri perjalanan jarak sedang, kecepatan ratarata sedang, dan jumlah jalan masuk tidak dibatasi;

3. Jalan Lokal : merupakan jalan yang berfungsi melayani angkutan setempat dengan ciri perjalanan jarak dekat, kecepatan rata-rata rendah, dan jalan masuk tidak dibatasi.

\section{Jalan Lingkungan}

merupakan jalan yang berfungsi melayani angkutan lingkungan dengan ciri perjalan jarak dekat, dan kecepatan rata-rata rendah.

\subsubsection{Klasifikasi Jalan Menurut Statusnya :}

1. Jalan nasional : merupakan jalan yang menghubungkan antar ibukota provinsi dan jalan strategis nasional.

Jalan nasional terdiri atas :

a. Jalan arteri primer

b. Jalan kolektor primer yang menghubungkan antar ibukota provinsi;

c. Jalan tol; dan

d. Jalan strategis nasional.

2. Jalan provinsi : merupakan jalan yang menghubungkan ibukota provinsi dengan ibukota 
kabupaten/kota dan jalan strategis provinsi.

3. Jalan Kabupaten : merupakan jalan yang menghubungkan ibukota kabupaten dengan ibukota kecamatan, antar ibukota kecamatan, ibukota kabupaten dengan pusat kegiatan lokal, antar pusat kegiatan lokal, serta jalan dalam wilayah kabupaten, dan jalan strategis kabupaten.

4. Jalan Kota : adalah jalan dalam sistem jaringan jalan sekunder yang menghubungkan antar pusat pelayanan dalam kota, menghubungkan pusat pelayanan dengan persil, menghubungkan antar persil, serta menghubungkan antar pusat permukiman yang berada di dalam kota.

5. Jalan Desa : merupakan jalan yang menghubungkan kawasan dan/atau antar permukiman di dalam desa, serta jalan lingkungan.

\subsection{Jenis Perkerasan Jalan}

2.3.1. Perkerasan Lentur

Perkerasan lentur adalah perkerasan jalan yang dibuat dengan menggunakan lapis pondasi agregat dan lapis permukaan dengan bahan pengikat aspal.

1. Perkerasan lentur pada permukaan tanah asli

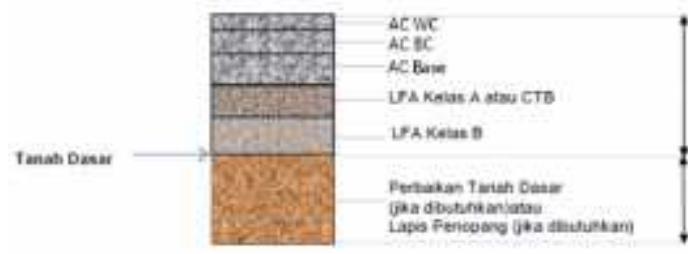

2. Perkerasan lentur pada timbunan.

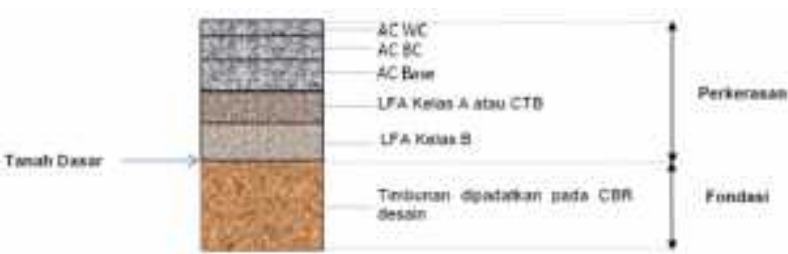

3. Perkerasan lentur pada galian.

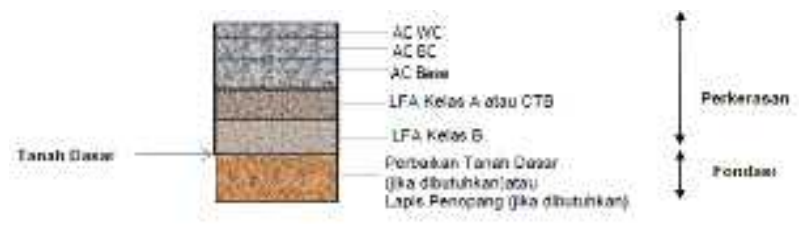

Gambar 1. Tipikal Struktur

Perkerasan Lentur (Lalu lintas berat)

\subsubsection{Perkerasan Kaku}

Perkerasan kaku adalah perkerasan yang menggunakan semen sebagai bahan pengikat.

1. Perkerasan kaku pada permukaan tanah asli

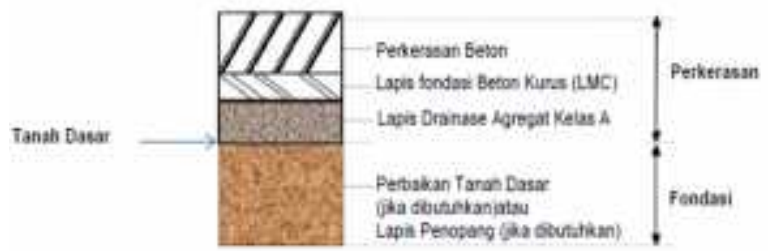

2. Perkerasan kaku pada timbunan.

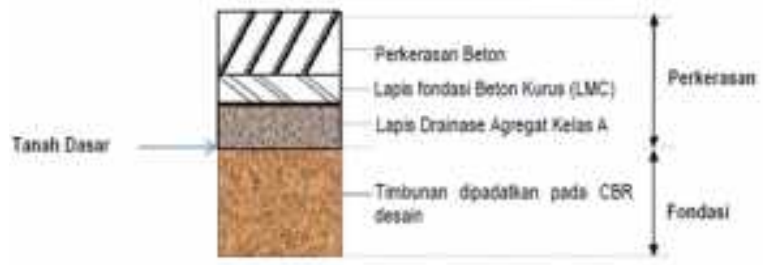

3. Perkerasan kaku pada galian.

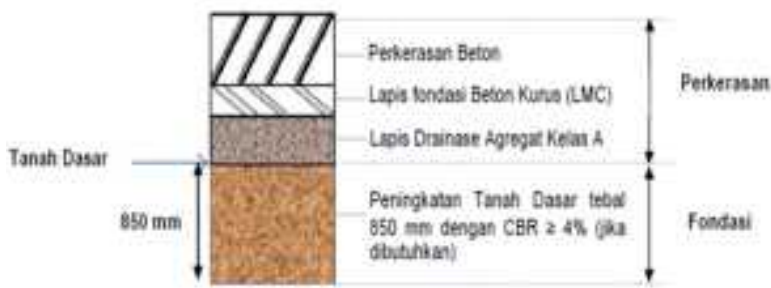

Gambar 2.Tipikal Struktur Perkerasan

Kaku

\subsubsection{Perkerasan Gabungan Kaku dan Lentur (Composite Pavement) \\ Perkerasan komposit merupakan gabungan kontruksi perkerasan kaku dan lapisan perkerasan lentur di atasnya,}


dimana kedua jenis perkerasan ini bekerja sama dalam memikul beban lalu lintas.

\section{METODE PENELITIAN}

\subsection{Lokasi Penelitian}

Lokasi penelitian yang dijadikan objek penelitian ini adalah Ruas Jalan Pramuka Kecamatan Gandus kota Palembang. Jalan Pramuka mempunyai panjang total $3,30 \mathrm{~km}$, STA yang dipilih pada penelitian ini adalah dimulai dari STA 00.00 s/d STA 03.60. Dipilihnya lokasi ini dikarenakan pada STA tersebut belum ada perkerasan, masih berupa timbunan tanah merah sedangkan selebihnya sudah ada perkerasan jalan.

\subsection{Prosedur Pelaksanaan Penelitian}

Prosedur pelaksanaan penelitian ini yaitu :

1. Study pustaka peraturan-peraturan yang berlaku dan penelitian terdahulu.

2. Pengumpulan data sekunder
a. Data lalu lintas Harian rata-rata (LHR)
b. Type ruas jalan.
c. Nilai CBR tanah dasar
d. Nilai Suku bunga.

3. Penentuan nilai parameter perencanaan tebal perkerasan.

a. Menghitung faktor pertumbuhan lalu lintas.

b. Menentukan jumlah lajur dan koefisien distribusi (C)

c. Menentukan faktor distribusi Lajur (DL) dan faktor distribusi arah (DD)

d. Menentukan nilai indeks Permukaan Awal (IPt) dan Indeks Permukaan Akhir $\left(\mathrm{IP}_{0}\right)$

e. Menentukan faktor kekuatan realtif (a) tiap lapisan.

4. Menghitung tebal perkerasan lentur.
a. Menentukan umur rencana.
b. Menghitung LHR selama umur rencana.
c. Menentukan nilai-nilai $\mathrm{CESA}_{4}$.
d. Menentukan nilai-nilai $\mathrm{CESA}_{5}$.

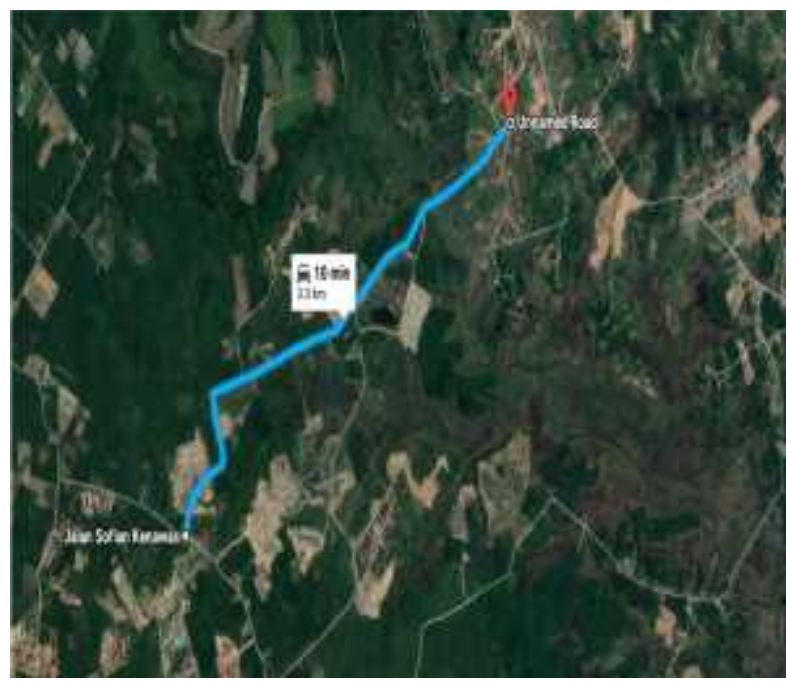

Gambar 3.Lokasi Penelitian

e. Menentukan struktur fondasi perkerasan.

f. Menentukan type perkerasan.

g. Menentukan struktur perkerasan yang memenuhi syarat.

h. Menentukan standar drainase bawah permukaan yang dibutuhkan.

i. Menggambar tebal lapisan perkerasan lentur hasil desain.

5. Menghitung tebal perkerasan kaku.

a. Menentukan umur rencana.

b. Menentukan volume kelompok sumbu kendaraan niaga.

c. Menentukan struktur fondasi perkerasan.

d. Menentukan struktur lapisan perkerasan beton.

e. Menentukan jenis sambungan (umumnya berupa sambungan dengan dowel)

f. Menentukan jenis bahu jalan (biasanya menggunakan bahu beton)

g. Menentukan detail desain yang meliputi dimensi pelat beton, penulangan pelat, posisi dowel \& tie bar, ketentuan sambungan dan sebagainya

6. Menghitung estimasi biaya kontruksi 
7. Menganalisis hasilnya untuk mendapatkan kesimpulan dan saran.

\section{HASIL DAN PEMBAHASAN}

4.1. Data Perencanaan

4.1.1. CBR tanah dasar

Adapun data CBR tanah dasar, penentuan

CBR desain dan grafik penentuan CBR

desain $90 \%$ pada lokasi dapat dilihat pada tabel 4.1. dibawah ini.

Tabel 1. CBR Tanah Dasar

STA

00.000

00.100

00.200

00.300

CBR

$2,17 \%$

$0,95 \%$

$0,87 \%$

$1,52 \%$

Tabel 2. Penentuan CBR Desain

\begin{tabular}{ccc}
\hline $\begin{array}{c}\text { CBR } \\
(\%)\end{array}$ & $\begin{array}{c}\text { Jumlah yang sama atau lebih } \\
\text { besar }\end{array}$ & $\begin{array}{c}\text { Persentase yang sama atau } \\
\text { lebih besar }\end{array}$ \\
\hline 0,87 & 4 & $4 / 4 \times 100 \%=100 \%$ \\
0,95 & 3 & $3 / 4 \times 100 \%=75 \%$ \\
1,52 & 2 & $2 / 4 \times 100 \%=50 \%$ \\
2,17 & 1 & $1 / 4 \times 100 \%=25 \%$ \\
\hline
\end{tabular}

\section{GRAFIK 1. PENENTUAN CBR $90 \%$}

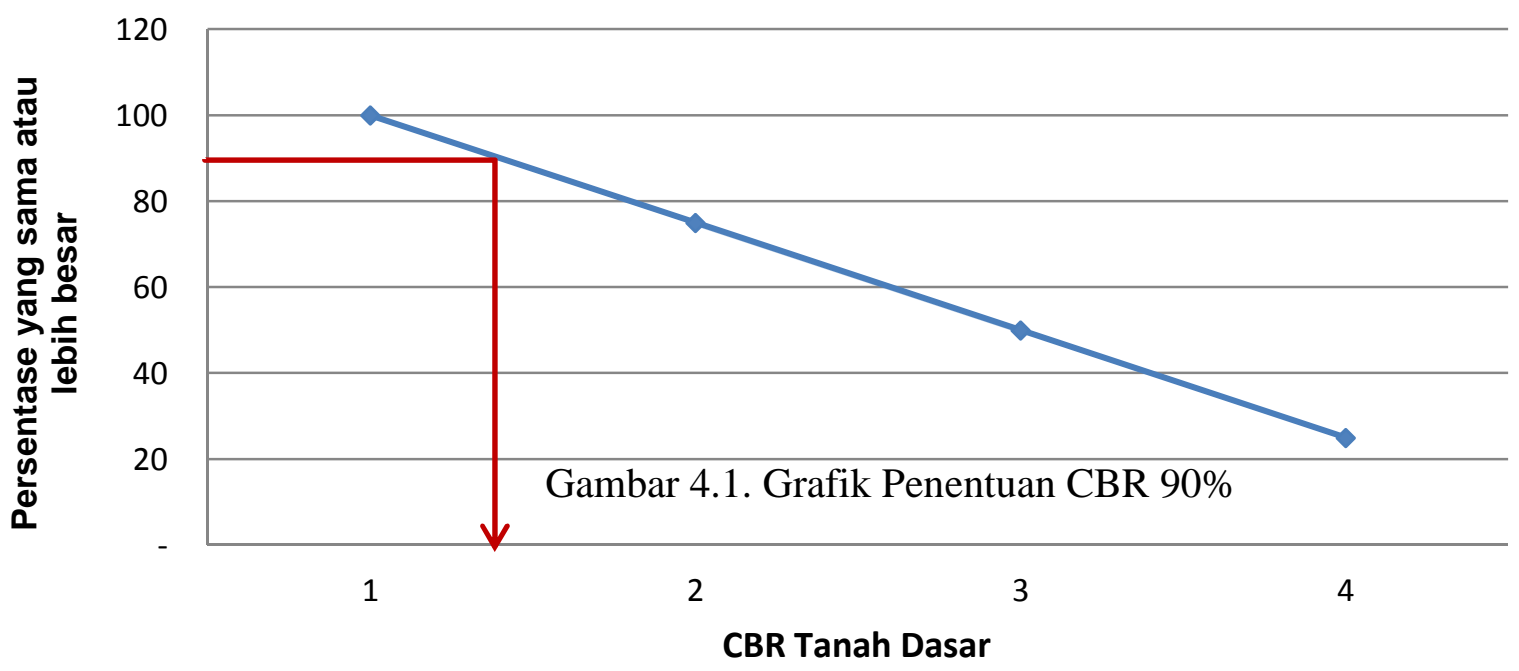

Dari grafik diatas maka diperoleh data CBR 90\% adalah 1,30 \%

\subsubsection{Volume lalu lintas harian rata-rata (LHR)}

Tabel 3. Perkiraan Lalu Lintas untuk Jalan Lalu Lintas Rendah

\begin{tabular}{|c|c|c|c|c|c|c|c|c|c|}
\hline Deskripsi Jalan & $\begin{array}{l}\text { LHR dua } \\
\text { arah } \\
\text { (kend/hari) }\end{array}$ & $\begin{array}{l}\text { Kendaraan } \\
\text { berat ( } \% \\
\text { dari lalu } \\
\text { lintas) }\end{array}$ & $\begin{array}{l}\text { Umur Ren- } \\
\text { cana (th) }\end{array}$ & $\begin{array}{l}\text { Pertumbuh } \\
\text { an Lalu } \\
\text { Lintas (\%) }\end{array}$ & $\begin{array}{c}\text { Faktor } \\
\text { Pengali } \\
\text { Pertumbuh- } \\
\text { an } \\
\text { kumulatif } \\
\text { talu lintas }\end{array}$ & $\begin{array}{l}\text { Keiompok } \\
\text { Sumbul } \\
\text { Kendaraan } \\
\text { Berat }\end{array}$ & $\begin{array}{l}\text { Kumulatif } \\
\text { HVAG } \\
\text { (kelompok } \\
\text { sumbu) }\end{array}$ & $\begin{array}{c}\text { Faktor } \\
\text { ESAHVAG }\end{array}$ & $\begin{array}{c}\text { Beban talu } \\
\text { tintasdesain } \\
\text { (aktuad) } \\
\text { (ESA4) }\end{array}$ \\
\hline $\begin{array}{l}\text { Jalan desa minor } \\
\text { dengan akses } \\
\text { kendaraan berat } \\
\text { terbatas }\end{array}$ & 30 & 3 & 20 & 1 & 22 & 2 & $14.454^{*}$ & 3,16 & $4,5 \times 10^{4}$ \\
\hline Jalan kecil dua arah & 90 & 3 & 20 & 1 & 22 & 2 & 21.681 & 3,16 & $7 \times 10^{4}$ \\
\hline Jalan lokal & 500 & 6 & 20 & 1 & 22 & 2,1 & 252.945 & 3,16 & $8 \times 10^{6}$ \\
\hline $\begin{array}{l}\text { Akses Tokar avemin } \\
\text { industri atau quarry }\end{array}$ & 500 & 8 & 20 & 3.5 & 28,2 & 2,3 & 473.478 & 3,16 & $1.5 \times 10^{6}$ \\
\hline Jaian kolektor & 2000 & 7 & 20 & 3.5 & 28,2 & 2,2 & $1.585,122$ & 3,16 & $5 \times 10^{4}$ \\
\hline
\end{tabular}




\subsubsection{Lebar Jalan}

Tabel 4. Ketentuan Lebar Badan Jalan \& Lebar Jalur Lalu Lintas

\begin{tabular}{|c|c|}
\hline Fungsi Jalan & $\begin{array}{c}\text { Lebar Badan } \\
\text { Jalan }(\mathrm{m})\end{array}$ \\
\hline Lokal & $\geq 7.5$ \\
\hline Kolektor & $\geq 9,0$ \\
\hline Arteri & $\geq 11,0$ \\
\hline
\end{tabular}

\begin{tabular}{|c|c|}
\hline Kelas Jalan & Lebar Jalur Lalu Lintas (m) \\
\hline Jalan Kecil & $>5,5$ \\
\hline \hline Jalan Sedang & $\geq 1 \times 7,0$ \\
\hline Jalan Raya & $2 \times \geq 7,0$ dgn median \\
\hline
\end{tabular}

Tabel 5. Lebar Transisi Jalan sesuai Surat Dirjen BM

\begin{tabular}{|c|c|c|c|c|}
\hline \multirow{2}{*}{ Fungsi Jalan } & \multicolumn{2}{|c|}{ Lebar Jalur Lalu Lintas (m) } & \multicolumn{2}{c|}{ Lebar Bahu (m) (kiri \& kanan) } \\
\cline { 2 - 3 } & Ideal & Transisi & Ideal & Transisi \\
\hline \multirow{2}{*}{ Lokal } & \multirow{2}{*}{5,5} & 3,5 & \multirow{2}{*}{$2 \times 1,0$} & $2 \times 2,00$ \\
\cline { 2 - 3 } & 6,0 & 4,5 & $2 \times 1,5$ & $2 \times 1,50$ \\
\hline Kolektor & 7,0 & 5,5 & $2 \times 1,75$ \\
\hline Arteri & 6,0 & 2,0 & $2 \times 2,50$ \\
\hline
\end{tabular}

Lebar Perkerasan $=4,5$ meter

Lebar Bahu Jalan $=2 \times 1,5$ meter

\subsection{Parameter Perencanaan}

\subsubsection{Umur Rencana (UR)}

Tabel 6. Umur Rencana Perkerasan Jalan Baru

\begin{tabular}{|c|c|c|}
\hline $\begin{array}{c}\text { Jenis } \\
\text { Perkerasan }\end{array}$ & Elemen Perkerasan & $\begin{array}{c}\text { Umur Rencana } \\
(\text { Tahun })^{(1)}\end{array}$ \\
\hline & Lapisan aspal dan lapisan berbutir ${ }^{(2)}$ & \\
\hline & Fondasi Jatan & \\
\hline \multirow[t]{2}{*}{$\begin{array}{l}\text { Perkerasan } \\
\text { lentur }\end{array}$} & $\begin{array}{l}\text { Semua perkerasan untuk daerah yang tidak } \\
\text { dimungkinkan pelapisan ulang (overlay), seperti jalan } \\
\text { perkotaan, underpass, jembatan terowongan }\end{array}$ & \\
\hline & Cement Treated Based (CTB) & \\
\hline $\begin{array}{l}\text { Perkerasan } \\
\text { kaku }\end{array}$ & $\begin{array}{l}\text { Lapis fondasi atas, lapis fondasi bawah, lapis beton } \\
\text { semen, dan fondasi jalan. }\end{array}$ & \\
\hline $\begin{array}{l}\text { Jalantanpa } \\
\text { penutup }\end{array}$ & Semua elemen (termasuk fondasi jalan) & Minimum 10 \\
\hline
\end{tabular}

Berdasarkan tabel diatas didapat umur rencana :

1. untuk perkerasan lentur $\mathbf{2 0}$ tahun dan; 
2. untuk perkerasan kaku umur rencana 40 tahun, karena jalan pramuka mempunyai volume lalu lintas rendah maka digunakan umur 20 tahun.

\subsubsection{Faktor Distribusi Arah $\left(\mathrm{D}_{\mathrm{D}}\right)$}

Faktor distribusi arah $\left(\mathrm{D}_{\mathrm{D}}\right)$ ditentukan adalah 0,5.

\subsubsection{Faktor Distribusi Lajur $\left(D_{L}\right)$}

Tabel 7. Faktor distribusi lajur $\left(\mathrm{D}_{\mathrm{L}}\right)$

\begin{tabular}{|c|c|}
\hline $\begin{array}{c}\text { Jumlah Lajur } \\
\text { Setiap arah }\end{array}$ & $\begin{array}{c}\text { Kendaraan niaga pada lajur desain } \\
\text { (\% terhadap populasi kendaraan niaga) }\end{array}$ \\
\hline 1 & 100 \\
\hline 2 & 80 \\
\hline 3 & 60 \\
\hline 4 & 50 \\
\hline
\end{tabular}

\subsubsection{Koefisien Distribusi $(\mathrm{C})$}

\section{Tabel 8. Koefisien distribusi (C)}

\begin{tabular}{|c|c|c|c|c|c|}
\hline \multirow{2}{*}{ Lebar Perkerasan $(\mathrm{Lp})$} & \multirow{2}{*}{$\begin{array}{c}\text { Jumlah } \\
\text { Lajur }\end{array}$} & \multicolumn{2}{|c|}{ Kendaraan Ringan* } & \multicolumn{2}{c|}{ Kendaraan Berat** } \\
\cline { 3 - 6 } & 1 & 1 arah & 2 arah & 1 arah & 2 arah \\
\hline $\mathrm{L}<4,50 \mathrm{~m}$ & 1 & 1,00 & 1,00 & 1,00 & 1.00 \\
$4,50 \mathrm{~m} \leq \mathrm{L}<8,00 \mathrm{~m}$ & 2 & 0,60 & 0,50 & $0,70 \rightarrow$ & 0,50 \\
$8,00 \mathrm{~m} \leq \mathrm{L}<11,25 \mathrm{~m}$ & 3 & 0,40 & 0,40 & 0,50 & 0,475 \\
$11,25 \leq \mathrm{L}<15,00 \mathrm{~m}$ & 4 & - & 0,30 & - & 0,45 \\
$15,00 \leq \mathrm{L}<18,75 \mathrm{~m}$ & 5 & - & 0,25 & - & 0,425 \\
$18,75 \leq \mathrm{L}<22,50 \mathrm{~m}$ & 6 & - & 0,20 & - & 0,40 \\
\hline
\end{tabular}

\subsubsection{Faktor Laju Pertumbuhan}

Faktor pertumbuhan dapat ditentukan sebagai berikut :

Tabel 9. Menentuan faktor laju pertumbuhan (i)

\begin{tabular}{|l|c|c|c|c|}
\hline & Jawa & Sumatera & Kalimantan & $\begin{array}{c}\text { Rata-rata } \\
\text { Indonesia }\end{array}$ \\
\hline Arteri dan perkotaan & 4,80 & 4,83 & 5,14 & 4,75 \\
\hline Kolektor rural & 3,50 & 3,50 & 3,50 & 3,50 \\
\hline Jalan desa & 1,00 & 1,00 & 1,00 & 1,00 \\
\hline
\end{tabular}

a. Menentukan faktor pertumbuhan lalu lintas dengan formula(1):

$$
\begin{aligned}
\mathrm{R}= & \frac{(1+0,0 l)^{U}-1}{0,0 l} \\
& =\frac{(1+0,0.1)^{2}-1}{0,0.1} \\
= & 22
\end{aligned}
$$

4.3. Perencanaan Tebal Perkerasan Lentur

4.3.1. Metode Bina Marga Pt T-01-2002-B

4.3.1.1.Analisis Lalu-lintas

Data lalu lintas tidak ada dan perkiraan lalu lintas rendah maka informasi dari Tabel 3 dapat digunakan.

Tabel 10. Nilai ESA menggunakan informasi tabel 3

\begin{tabular}{c|c|c|c|c}
\hline Jenis Kendaraan & LHR 2018 & $\begin{array}{c}\text { Kumulatif HVAG } \\
\text { (kelompok }\end{array}$ & $\begin{array}{c}\text { Faktor } \\
\text { ESA }\end{array}$ & $\begin{array}{c}\text { Beban Lalu } \\
\text { lintas Desain }\end{array}$ \\
\hline
\end{tabular}




\begin{tabular}{l|c|c|c|c}
\hline & & sumbu) & HVAG & (actual) (ESA4) \\
\hline $\begin{array}{l}\text { Mobil Penumpang dan } \\
\text { kendaran ringan } \\
\text { lainnya }\end{array}$ & $500 \times 94 \%=470$ & - & - & - \\
\hline Kendaraan berat & $500 \times 6 \%=30$ & 252.945 & 3,16 & $8 \times 10^{5}$ \\
\hline
\end{tabular}

Kontrol dengan menggunakan formula (2), (3), (4) dan (5)

$$
\begin{aligned}
\hat{\mathrm{W}}_{18}=\mathrm{ESAL} & =\sum L \quad x E \\
& =(30 \times 2,1) \times 3,16 \\
& =199,08 \ldots \ldots \ldots \ldots
\end{aligned}
$$

$$
\begin{aligned}
\mathrm{W}_{18} & =\mathrm{D}_{\mathrm{D}} \times \mathrm{D}_{\mathrm{L}} \times \hat{\mathrm{W}}_{18} \\
& =0,5 \times 100 \% \times 199,08 \\
& =99,54 \ldots \ldots \ldots \ldots \ldots
\end{aligned}
$$

$\mathrm{W}_{18}$ pertahun $=\mathrm{D}_{\mathrm{D}} \times \mathrm{D}_{\mathrm{L}} \times \hat{\mathrm{W}}_{18} \times 365$

$$
\begin{aligned}
& =\mathrm{W}_{18} \times 365 \\
& =99,54 \times 365 \\
& =36.332,10 \ldots
\end{aligned}
$$

$\mathrm{Wt}$

$$
\begin{aligned}
& =\mathrm{W}_{18 \text { pertahun }} \times \mathrm{R} \\
& =36.332,10 \times 22 \\
& =799.306,20 \\
& =8 \times 10^{5} \ldots \ldots \ldots \ldots
\end{aligned}
$$

\begin{tabular}{|c|c|c|}
\hline \multirow{2}{*}{$\begin{array}{l}\text { Klasifikasi } \\
\text { Jalan }\end{array}$} & \multicolumn{2}{|c|}{$\begin{array}{l}\text { Rekomendasi tingkat } \\
\text { reliabilitas }\end{array}$} \\
\hline & Perkotaan & Antar Kota \\
\hline $\begin{array}{c}\text { Bebas } \\
\text { Hambatan }\end{array}$ & $85-99,99$ & $80-99,9$ \\
\hline
\end{tabular}

\section{(OK)}

\subsubsection{Modulus Reselien}

$$
\begin{aligned}
\mathrm{M}_{\mathrm{R}}(\mathrm{psi}) & =1.500 \times \mathrm{CBR}_{\text {tanah efektif }} \\
& =1.500 \times 5 \\
& =7.500 \mathrm{psi} \ldots \ldots \ldots \ldots(6) \ldots \ldots
\end{aligned}
$$

\subsubsection{Design Serviceability Loss}

Indeks Permukaan Akhir $(\mathrm{IPt})=2,5$

Indeks Permukaan Awal $\left(\mathrm{IP}_{0}\right)=4,2$

Serviceability Loss

$$
\begin{aligned}
\text { PSI } & =\mathrm{IPt}-\mathrm{IP}_{0} \\
& =4,2-2,5 \\
& =1,7
\end{aligned}
$$

\subsubsection{Reliabilitas $(R)$}

Tabel 11. Rekomendasi Tingkat Reliabilitas

\begin{tabular}{|c|c|c|}
\hline Arteri & $80-99$ & $75-95$ \\
\hline Kolektor & $80-95$ & $75-95$ \\
\hline Lokal & $50-80$ & $50-80$ \\
\hline
\end{tabular}

Nilai Relaibiltas yang ambil sebesar 95\%, Deviasi standar $\left(\mathrm{S}_{0}\right)$ diambil nilai tengah yaitu 0,45

\subsubsection{Standar Deviasi Normal $\left(Z_{R}\right)$}

Tabel 4.12. Nilai Penyimpangan Normal Standar $\left(Z_{R}\right)$ untuk Tingkat Reliabilitas

\section{Tertentu}

\begin{tabular}{|c|c|}
\hline Reliabiltas, $R(\%)$ & $\begin{array}{c}\text { Standar Normal } \\
\text { Deviate, } Z_{\mathrm{R}}\end{array}$ \\
\hline 50 & 0,000 \\
\hline 60 & $-0,253$ \\
\hline 70 & $-0,524$ \\
\hline 75 & $-0,674$ \\
\hline 80 & $-0,841$ \\
\hline 85 & $-1,037$ \\
\hline 90 & $-1,282$ \\
\hline 91 & $-1,340$ \\
\hline 92 & $-1,405$ \\
\hline 93 & $-1,476$ \\
\hline 94 & $-1,555$ \\
\hline 95 & $-1,645$ \\
\hline 90 & $-1,751$ \\
\hline 97 & $-1,881$ \\
\hline 98 & $-2,054$ \\
\hline 99 & $-2,327$ \\
\hline 99,9 & $-3,090$ \\
\hline 99,99 & $-3,750$ \\
\hline
\end{tabular}

Nilai yang didapat $-1,645$

\subsubsection{Koefisien Kekuatan Relatif}

Komposisi lapisan yang akan direncanakan pada masing-masing lapiasan sebagai berikut :

1. Lapis Permukan Beton Aspal

$$
\begin{array}{ll}
\mathrm{E}_{\mathrm{AC}} \text { non modifikasi } & =220.000 \mathrm{psi} \\
\mathrm{a}_{1} & =0,315
\end{array}
$$

2. Lapis Pondasi Granular dengan Nilai 


$$
\begin{array}{ll}
\text { Modulus Base } & =29.400 \mathrm{psi} \\
\mathrm{a}_{2} & =0,138
\end{array}
$$

3. Lapis Pondasi Bawah Granular Modulus Sub-Base $=17.900 \mathrm{psi}$

$$
\mathrm{a}_{3} \quad=0,127
$$

\subsubsection{Nilai Structural Number (SN)}

Parameter untuk menentukan nilai SN

Realibilitas (R) $\quad=95 \%$

Standar Deviasi (So) $\quad=0,45$

$\mathrm{Wt} \quad=5 \times 10^{6}$

Modulus Resilien $\left(\mathrm{M}_{\mathrm{R}}\right)=7.500 \mathrm{psi}$

PSI $\quad=1,7$

Menggunakan Nomogram(Pd T-01-2002-

B), didapat :

$\begin{array}{ll}\mathrm{SN} & =3,50 \\ \mathrm{SN}_{1} & =2,10 \\ \mathrm{SN}_{2} & =2,50\end{array}$

\subsubsection{Menghitung Tebal Lapisan Perkerasan}

Menggunakan Persamaan (8)

$\mathrm{SN}=\mathrm{a}_{1} \mathrm{D}_{1}+\mathrm{a}_{2} \mathrm{D}_{2}+\mathrm{a}_{3} \mathrm{D}_{3}$

1. $*_{1}{ }_{1}=\frac{s_{1}}{u_{1}}=\frac{2,1}{0,3}=6,67$ inch

$\mathrm{SN}^{*}{ }_{1}=\mathrm{a}_{1} \mathrm{D}^{*}=0,315 \times 7=2,205$

2. $*_{2}=\frac{s_{2}-s_{1}}{u_{2}}=\frac{2,5-2,2}{0,1}$

$$
=2,137 \text { inch }
$$$$
\mathrm{SN}^{*}{ }_{2}=\mathrm{a}_{2} \mathrm{D} *_{2}=0,138 \times 3=0,414
$$

3. $\mathrm{D}_{3}=\frac{s_{3}-s_{1}-s_{2}}{u_{3}}$

$$
=\frac{3,5-2,2^{u_{3}}-0,4}{0,1}=6,937 \text { inch }
$$

Menggunakan persamaan

$$
\begin{aligned}
\text { T surface (non mod) } & =17,298(\mathrm{~L})^{0,1597} \\
& =17,298(0,8)^{0,1597} \\
& =16,7 \mathrm{~cm} \mathrm{\ldots ...(8)}
\end{aligned}
$$

$\mathrm{T}$ base

$$
\begin{aligned}
& =8,4729(\mathrm{~L})^{0,1202} \\
& =8,4729(0,8)^{0,1202} \\
& =8,18 \mathrm{~cm} \ldots \ldots(9)
\end{aligned}
$$

T sub-base

$$
\begin{aligned}
= & \left(0,0735 \mathrm{CBR}^{2}-1,528 \mathrm{CBR}+8,5729\right) \\
& (\ln \mathrm{L})-0,0931 \mathrm{CBR}^{3}+2,2316 \mathrm{CBR}^{2}- \\
& 21,668 \mathrm{CBR}+82,347 \\
= & \left(0,0735^{*} 5^{2}-1,528 * 5+8,5729\right)(\ln \\
& 0,8)-0,0931 * 5^{3}+2,2316^{*} 5^{2}- \\
& 21,668 * 5+82,347 \\
= & 17,541 \mathrm{~cm} \ldots \ldots \ldots \ldots \ldots \ldots \ldots \ldots(10)
\end{aligned}
$$

Tabel 13. Hasil Tebal Lapisan dengan Metode

\begin{tabular}{c|c}
\multicolumn{2}{c}{ Pt T-01-2002-B (Alternatif 1) } \\
\hline Lapisan & Tebal $(\mathbf{m m})$ \\
\hline AC WC & 180 \\
\hline LPA Kelas A & 100 \\
\hline LPA Kelas B & 200 \\
\hline
\end{tabular}

4.3.2. Metode Manual Perkerasan Jalan 2017 (No. 04/SE/Db/2017)

\subsubsection{Menghitung ESA5}

Dari Analisis sebelumnya didapat

ESA4 $=8 \times 10^{5}$

ESA5 $=$ TM $\times$ ESA4

$=1,8 \times 8 \times 10^{5}$

$=1,4 \times 10^{6}$

\subsubsection{Penentuan Tebal Lapis Perkerasan}

Untuk lalu lintas pada lajur rencana 1,4 x $10^{6}$ ESA5 alternatif desain perkerasan lentur adalah Bagan Desain - 3B FFF1

Tabel 4.14. Hasil Tebal Lapisan dengan Metode Manual Perkerasan Jalan No. 04/SE/Db/2017 Alternatif 2

\begin{tabular}{c|c}
\hline Lapisan & Tebal $(\mathbf{m m})$ \\
\hline AC WC & 40 \\
\hline AC BC & 60 \\
\hline LPA Kelas A & 400 \\
\hline
\end{tabular}

4.4. Perencanaan Tebal Perkerasan Kaku 4.4.1. Metode Bina Marga Pd T-14-2003 4.4.1.1. Analisis Lalu-lintas 
Tabel 15. Nilai JSKN menggunakan informasi tabel 4..3

\begin{tabular}{|c|c|c|c|}
\hline Jenis Kendaraan & LHR 2018 & $\begin{array}{c}\text { Kelompok } \\
\begin{array}{c}\text { Sumbu/Kendaraan } \\
\text { berat }\end{array}\end{array}$ & $\begin{array}{c}\text { Kumulatif HVAG } \\
\text { (kelompok sumbu) } \\
2018-2038\end{array}$ \\
\hline $\begin{array}{l}\text { Mobil Penumpang dan } \\
\text { kendaran ringan lainnya }\end{array}$ & $500 \times 94 \%=470$ & & - \\
\hline Kendarran berat & $500 \times 6 \%=30$ & 2,1 & 252.945 \\
\hline \multicolumn{2}{|c|}{$\begin{array}{l}\text { Kontrol dengan menggunakan formula } \\
\text { (12) dan atau formula (13) }\end{array}$} & \multicolumn{2}{|c|}{$\begin{array}{l}\text { Perkerasan Beton semen dengan sambungan } \\
\text { tanpa tulangan. }\end{array}$} \\
\hline \multicolumn{2}{|l|}{ JSKNrencana } & \multicolumn{2}{|c|}{ Umur rencana $=20$ Tahun } \\
\hline \multicolumn{2}{|c|}{$=$ JSKNH x $365 \times \mathrm{R} \times \mathrm{C} \ldots \ldots \ldots \ldots$ (13) } & \multicolumn{2}{|l|}{ Mutu Beton = } \\
\hline \multirow{2}{*}{\multicolumn{2}{|c|}{$=(30 \times 2,2) \times 365 \times 22 \times 0,5=252.945$}} & \multicolumn{2}{|l|}{ Bahu pelat beton $=\mathrm{Ya}$} \\
\hline & & \multirow{2}{*}{\multicolumn{2}{|c|}{ Tulangan distribusi retak $=\mathrm{Ya}$}} \\
\hline \multicolumn{2}{|l|}{ JSKN rencana } & & \\
\hline \multirow{2}{*}{\multicolumn{2}{|c|}{$\begin{aligned}= & \left(\operatorname{LHR}_{\mathrm{JK}} \times \mathrm{VDF}_{\mathrm{JK}}\right) \times 365 \times \mathrm{D}_{\mathrm{D}} \times \mathrm{D}_{\mathrm{L}} \\
& \mathrm{x} \ldots \ldots \ldots \ldots \ldots \ldots \ldots \ldots \ldots \ldots \ldots \ldots \ldots \ldots \ldots \ldots \ldots \ldots \ldots \ldots\end{aligned}$}} & Dowel (ruji) & $=$ tidak diperlukan \\
\hline & & Lapis beton kurus & $=$ tidak diperlukan \\
\hline \multicolumn{2}{|c|}{$=(30 \times 2,2) \times 365 \times 0,5 \times 100 \% \times 22$} & \multicolumn{2}{|c|}{ Lapis Fondasi Kelas A $=125 \mathrm{~mm}$} \\
\hline & \multicolumn{2}{|l|}{ Jarak Sambungan } \\
\hline
\end{tabular}

Baik dari tabel ataupun formula nilai JSKN sama yaitu 252.945

\subsubsection{Perhitungan Repetisi Sumbu yang Terjadi}

Karena lalu lintas rendah maka perhitungan tidak dapat dilanjutkan. Tahap selanjutnya adalah dengan metode Manual Perkerasan Jalan 2017 (No. 04/SE/Db/2017).

\subsubsection{Metode Manual Perkerasan Jalan 2017 (No. 04/SE/Db/2017)}

\subsubsection{Perhitungan Tebal Pelat Beton.}

Karena Lalu lintas rendah maka perhitungan tebal pelat dapat menggunakan Bagan desain-4.A

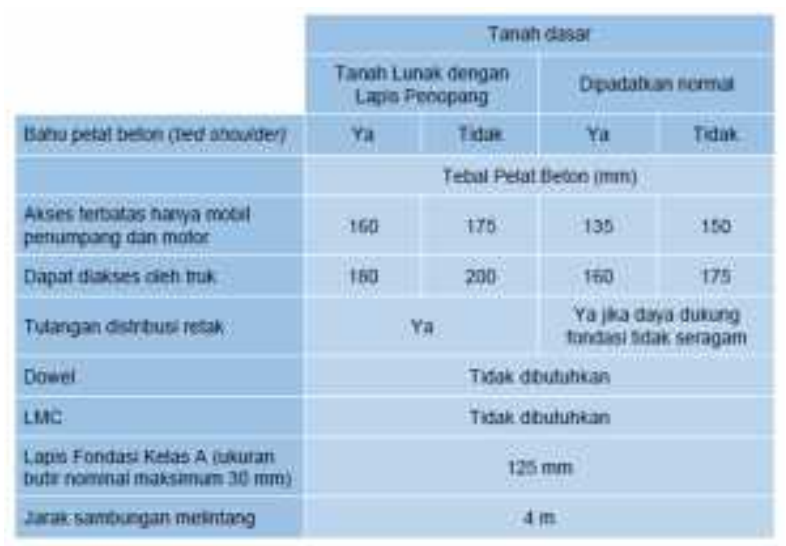

\subsubsection{Perhitungan Tulangan (Pd T-14-2003)}

Perkerasan beton bersambung tanpa tulangan

$$
\begin{aligned}
& >\text { Tebal Pelat } \quad=180 \mathrm{~mm} \\
& >\text { Lebar pelat } \quad=2 \times 2,5 \mathrm{~m} \\
& >\text { Panjang pelat } \quad=4,0 \mathrm{~m} \\
& >\text { Batang Pengikat } \\
& \mathbf{A}_{\mathbf{t}}=204 \times \mathrm{b} \times \mathrm{h} \\
& =204 \times 4 \times 0,18 \\
& =146,88 \mathrm{~mm}^{2} \text {------- } \varnothing=13,7 \\
& \approx 16 \mathrm{~mm} \\
& I=(38,3 \times \emptyset)+75 \\
& =(38,3 \times 16)+75 \\
& =687,8 \mathrm{~mm} \approx 70 \mathrm{~cm}
\end{aligned}
$$

Batang pengikat digunakan baja ulir Ø $16 \mathrm{~mm}$, panjang $70 \mathrm{~cm}$, jarak 75 $\mathrm{cm}$.

$>$ Sambungan susut dipasang setiap jarak 4,0 m

$>\quad$ Ukuran Ruji (Tabel 2.21)

Tabel 16. Diameter Ruji

\begin{tabular}{|c|c|c|}
\hline No. & $\begin{array}{c}\text { Tebal pelat } \\
\text { beton, } \mathrm{h}(\mathrm{mm})\end{array}$ & $\begin{array}{c}\text { Diameter } \\
\text { Ruji }(\mathrm{mm})\end{array}$ \\
\hline 1 & $125<\mathrm{h} \leq 140$ & 20 \\
\hline 2 & $140<\mathrm{h} \leq 160$ & 24 \\
\hline 3 & $160<\mathrm{h} \leq 190$ & 28 \\
\hline 4 & $190<\mathrm{h} \leq 220$ & 33 \\
\hline
\end{tabular}


Ø $28 \mathrm{~mm}$, panjang $45 \mathrm{~cm}$, jarak $30 \mathrm{~cm}$

\subsection{Pebandingan Biaya Kontruksi}

4.5.1. Analisis Biaya Kontruksi

Tabel 17. Analisis Biaya Kontruksi Pekerasan Lentur (alternatif 1)

\begin{tabular}{|c|c|c|c|c|c|}
\hline No & Uraian & Sat & Volume & $\begin{array}{c}\text { Harga Satuan } \\
(\boldsymbol{R p})\end{array}$ & $\begin{array}{c}\text { Jumlah Harga } \\
(\text { Rp })\end{array}$ \\
\hline \multirow[t]{3}{*}{1.} & UMUM & & & & \\
\hline & Mobilisasi & ls & 1 & $12.725 .000,00$ & $12.725 .000,00$ \\
\hline & $\begin{array}{l}\text { Manajemen \& Keselamatan lalu- } \\
\text { lintas }\end{array}$ & ls & 1 & $3.730 .000,00$ & $3.730 .000,00$ \\
\hline \multirow[t]{3}{*}{2.} & PEKERJAAN PONDASI & & & & \\
\hline & Lapis Pondasi Agregat Kls. A & $\mathrm{m}^{3}$ & 162,00 & $777.679,92$ & $125.984 .147,35$ \\
\hline & Lapis Pondasi Agregat Kls. B & $\mathrm{m}^{3}$ & 324,00 & $713.331,44$ & 231.119.386,32 \\
\hline \multirow[t]{3}{*}{3.} & PERKERASAN ASPAL & & & & \\
\hline & Lapis Resap Pengikat & liter & $1.296,00$ & $14.544,80$ & $18.850 .057,04$ \\
\hline & Lapis Perekat & liter & $1.134,00$ & $14.966,76$ & $16.972 .305,84$ \\
\hline \multirow[t]{3}{*}{. } & Laston Lapis Aus (AC-WC) & ton & 147,10 & $1.672 .786,13$ & $246.060 .147,88$ \\
\hline & Laston Lapis Antara (AC-BC) & ton & 225,50 & $1.587 .913,59$ & $358.080 .865,32$ \\
\hline & Laston Lapis Pondasi (AC-Base) & ton & 300,67 & $1.443 .719,45$ & $434.086 .015,76$ \\
\hline & Jumlah & & & & 1.447.607.925,- \\
\hline & Dibulatkan & & & & 1.447.607.000,- \\
\hline
\end{tabular}

Tabel 18. Analisis Biaya Kontruksi Pekerasan Lentur (alternatif 2)

\begin{tabular}{|c|c|c|c|c|c|}
\hline No & Uraian & Sat & Volume & $\begin{array}{c}\text { Harga Satuan } \\
(\text { Rp })\end{array}$ & $\begin{array}{c}\text { Jumlah Harga } \\
\text { (Rp) }\end{array}$ \\
\hline \multirow[t]{3}{*}{1.} & UMUM & & & & \\
\hline & Mobilisasi & ls & 1 & $12.725 .000,00$ & $12.725 .000,00$ \\
\hline & $\begin{array}{l}\text { Manajemen \& Keselamatan lalu- } \\
\text { lintas }\end{array}$ & ls & 1 & $3.730 .000,00$ & $3.730 .000,00$ \\
\hline \multirow[t]{2}{*}{2.} & PEKERJAAN PONDASI & & & & \\
\hline & Lapis Pondasi Agregat Kls. A & $\mathrm{m}^{3}$ & 648,00 & $777.679,92$ & $503.936 .589,41$ \\
\hline \multirow[t]{7}{*}{3.} & PERKERASAN ASPAL & & & & \\
\hline & Lapis Resap Pengikat & liter & $1.296,00$ & $14.544,80$ & $18.850 .057,04$ \\
\hline & Lapis Perekat & liter & 567,00 & $14.966,76$ & $8.486 .152,92$ \\
\hline & Laston Lapis Aus (AC-WC) & ton & 147,10 & $1.672 .786,13$ & $246.060 .147,88$ \\
\hline & Laston Lapis Antara (AC-BC) & ton & 225,50 & $1.587 .913,59$ & $358.080 .865,32$ \\
\hline & Jumlah & & & & 1.151.868.812,- \\
\hline & Dibulatkan & & & & 1.151.868.000,- \\
\hline
\end{tabular}


Tabel 19. Analisis Biaya Kontruksi Pekerasan Kaku

\begin{tabular}{|c|c|c|c|c|c|}
\hline No & Uraian & Sat & Volume & $\begin{array}{c}\text { Harga Satuan } \\
(\boldsymbol{R p})\end{array}$ & $\begin{array}{c}\text { Jumlah Harga } \\
(\text { Rp })\end{array}$ \\
\hline \multirow[t]{3}{*}{1.} & UMUM & & & & \\
\hline & Mobilisasi & ls & 1 & $9.735 .000,00$ & $15.945 .000,00$ \\
\hline & $\begin{array}{l}\text { Manajemen \& Keselamatan lalu- } \\
\text { lintas }\end{array}$ & ls & 1 & $3.730 .000,00$ & $7.040 .000,00$ \\
\hline \multirow[t]{3}{*}{2.} & PEKERJAAN PONDASI & & & & \\
\hline & Lapis Pondasi Agregat Kls. A & $\mathrm{m}^{3}$ & 202,50 & $777.679,92$ & $157.480 .184,19$ \\
\hline & $\begin{array}{l}\text { Perkerasan Beton } \text { Semen } \\
(\text { K.300) }\end{array}$ & $\mathrm{m}^{3}$ & 291,60 & $1.770 .078,06$ & $516.154 .762,30$ \\
\hline \multirow[t]{5}{*}{3.} & PERKERASAN ASPAL & & & & \\
\hline & Lapis Resap Pengikat & liter & $1.296,00$ & $14.544,80$ & $18.850 .057,04$ \\
\hline & Laston Lapis Aus (AC-WC) & ton & 91,94 & $1.672 .786,13$ & $153.787 .592,43$ \\
\hline & Jumlah & & & & 859.737.595,96- \\
\hline & Dibulatkan & & & & 859.737.000,- \\
\hline
\end{tabular}

\subsubsection{Analisis Perbandingan Biaya Kontruksi}

Tabel 20. Perbandingan Biaya Kontruksi

\begin{tabular}{|c|c|c|c|c|}
\hline \multirow[b]{2}{*}{ No } & \multirow[b]{2}{*}{ Jenis Perkerasan } & \multicolumn{2}{|c|}{ Biaya } & \multirow[b]{2}{*}{$\begin{array}{c}\text { Persentase } \\
\text { Biaya }\end{array}$} \\
\hline & & $\begin{array}{c}\text { Biaya Kontruksi } \\
(\text { Rp })\end{array}$ & $\begin{array}{l}\text { B iaya per } \mathrm{m}^{\prime} \\
(\boldsymbol{R} \boldsymbol{p})\end{array}$ & \\
\hline 1. & Perkerasan Lentur & 1.151.869.000,- & $3.199 .633,33$ & $100,00 \%$ \\
\hline \multirow[t]{2}{*}{2.} & Perkerasan Kaku & 859.737.000,-- & $2.388 .158,33$ & $74,64 \%$ \\
\hline & Selisih Biaya & 292.131.000,- & $811.475,55$ & $25,36 \%$ \\
\hline
\end{tabular}

\section{KESIMPULAN}

Berdasarkan hasil penelitian dan pembahasan yang telah dilakukan, maka dapat disimpulkan bahwa :

1. Untuk perkerasan lentur didapat tebal lapis permukaan AC-WC $40 \mathrm{~mm}$ dan AC-BC $60 \mathrm{~mm}$ serta tebal lapis pondasi agregat $400 \mathrm{~mm}$.

2. Untuk pekerasan kaku didapat tebal lapis permukaan (AC-WC) $25 \mathrm{~mm}$ (minimum), lapis perkerasan beton (kaku) $180 \mathrm{~mm}$ dan lapis pondasi agregat kelas A $125 \mathrm{~mm}$.

3. Biaya kontruksi Perkerasan Lentur Rp. 1.151.869.000,-

4. Biaya kontruksi Perkerasan Kaku (Beton Semen) Rp. 859.737.000,-

5. Dari perbandingan biaya kontruksi menunjukan bahwa perkerasan kaku dapat menghemat biaya sebesar $25,36 \%$

6. Untuk daerah yang mempunyai lalu lintas rendah menunjukan bahwa Perkerasan kaku lebih murah jika dibandingkan dengan perkerasan lentur.

\section{DAFTAR PUSTAKA}

Departemen Pekerjaan Umum. (2005). Pedoman Perencaan Tebal lapis tambah perkerasan lentur dengan metode lendutan, Pd T-052005-B. Jakarta.

Departemen Permukiman dan Prasarana Wilayah. (2002). Pedoman Perencanaan tebal 
Perkerasan Lentur, Pt T-01-2002 B. Jakarta.

Departemen Permukiman dan Prasarana Wilayah. (2003). Perencanaan Perkerasan Jalan Beton Semen, Pd T-14-2003. Jakarta.

Direktorat Jenderal Bina Marga. (2017). Manual Perkerasan Jalan (Revisi Juni 2017) Nomor 04/SE/Db/2017. Jakarta.

Direktorat Jenderal Bina Marga Kementerian Pekerjaan Umum. (2011). Desain Perkerasan Jalan Lentur (Interim) No. 002/P/BM/2011 . Jakarta.

Kementerian Pekerjaan Umum. (2011). Peraturan Menteri Pekerjaan Umum Nomor 19/PRT/M/2011 Tentang Persyaratan Jalan dan Kriteria Perencanaan Teknis Jalan ( Berita Negara Republik Indonesia Tahun 2011 Nomor 900 ). Jakarta.

Pemerintah Indonesia. (2004). Undang Undang Republik Indonesia Nomor 38 Tahun
2004 Tentang Jalan ( Lembaran Negara Republik Indonesia Tahun 2004 Nomor 132, Tambahan Lembaran Negara Nomor 4444 ). Jakarta.

Pemerintah Indonesia. (2006). Peraturan Pemerintah Republik Indonesia Nomor 34 Tahun 2006 Tentang Jalan ( Lembaran Negara Republik Indonesia Tahun 2006 Nomor 86, Tambahan Lembaran Negara Republik Indonesia Nomor 4655 ). Jakarta.

Pemerintah Indonesia. (2009). Undang - Undang Republik Indonesia Nomor 22 Tahun 2009 Tentang Lalu Lintas dan Angkutan Jalan (Lembaran Negara Republik Indonesia tahun 2009 Nomor 96, Tambahan Lembaran Negara Republik Indonesia Nomor 2028 ). Jakarta.

PT. Cipta Wira Perdana. (2017). Pekerjaan Survey dan Pendataan Jalan Dalam Kota Palembang Zona 2. Palembang. 